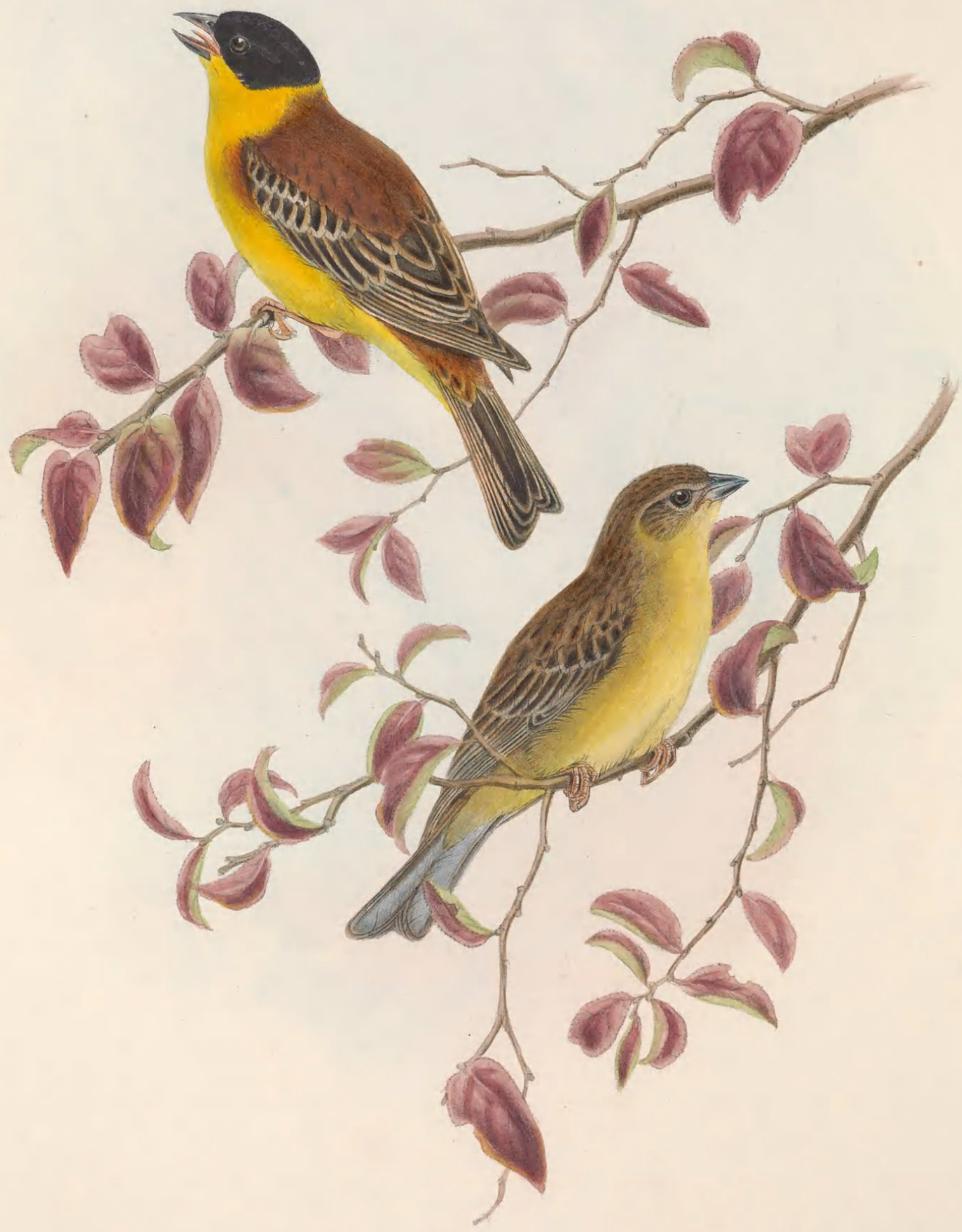




\title{
EUSPIZA MELANOCEPHALA.
}

\author{
Black-headed Euspiza.
}

\author{
Emberiza melanocephala, Scop. Ann. Hist.-Nat., tom. i. p. 142. \\ Tanagra melanictera, Lath. Ind. Orn., vol. i. p. 123. \\ Xanthornus caucasicus, Pall. Zoog. Rosso-Asiat., tom. i. p. 428. no. 74. \\ Fringilla crocea, Vieill. Hist. Nat. des Ois. Chant., p. 51, tab. 27. \\ Passerina melanocepha, Vieill. Ency. Méth. Orn., part. iii. p. 940. \\ Emberiza granativora, Ménétr. Cat. des Objets de Zool. du Caucase, tom. i. p. 40. no. 29. \\ Euspiza melanocephala, Bonap. Consp. Gen. Av., tom. i. p. 468, Euspiza, sp. 1. \\ simillima, Blyth, Journ. Asiat. Soc. Beng., vol. xxiii. p. 811. \\ Granativora simillima, Bonap. Comp. Rend. de l’Acad. des Sci., 1853.
}

Judging from the number of continental birds which have been added to our avifauna during the last twenty years, we may reasonably infer that others will have to be included, and that the List of British Birds, will ever remain incomplete. My duty, as the author of the present work, is to render it as perfect as may be up to the date of its completion; and hence I am induced to give here a figure and account of the Black-headed Bunting, which, so far as positive evidence can be obtained short of seeing the bird alive or in the flesh, is one of the wanderers above alluded to, of which a fine adult female was brought to me by $\mathrm{Mr}$. Robert Brazener, of Brighton, in the latter part of 1868, to ascertain what it might be. He informed me that he had shot it on the 3rd of November of that year, near Mr. Ballard's windmill on Brighton Racecourse, while "it was following a flock of Yellow Hammers." His two sons were with him at the time. On an examination of the bird, a number of embryo eggs were found in the ovarium. After questioning Brazener as to the circumstances of its acquisition, noting the perfection of the skin, its freshness and the mode of preparation, and ascertaining, as far as might be, the probability of its having been mixed with continental examples from which it had not been distinguished, I could come to no other conclusion than that his statemènt was correct, and that the bird had really been killed in this country. From Mr. Brazener the specimen passed, through my instrumentality, into the possession of T. J. Monk, Esq., of Lewes, whose collection (comprising as it does the greater number of the rarce aves taken in Sussex) I considered would be its most appropriate resting-place. The occurrence of the bird on our coast cannot be regarded as an unlikely event when we remember that Blasius and Gätke include it among the birds of Heligoland, although there also it must be regarded as a straggler, its proper home being the southern countries of Europe and Western India, as will be seen by the following notes recorded by various writers both English and foreign.

Dr. Bree, speaking of the bird in his valuable contribution to ornithological literature, 'A History of the Birds of Europe not observed in the British Isles,' says :-

"The Black-headed Bunting is an inhabitant of the southern parts of Europe and Asia Minor. It inhabits the Caucasus, and is very common in Georgia, about Tiflis, and in Greece, and is not rare in Dalmatia. It is common throughout the Levant, and is sufficiently so, according to Temminck, in Istria, in the neighbourhood of Trieste, in the bushes and slopes of the hills which border the Adriatic. It has occasionally, but accidentally, been found in Lombardy, Provence, Saxony, and in the neighbourhood of Vienna.

"It sings very agreeably, preferring, while so engaged, to perch on some post in the open country.

"It nests upon shrubs, particularly, according to Degland, on " the Bariurus aculeatus, and not far from the ground. It lays from four to five whitish eggs, covered with very small spots and dots of a more or less ashy grey ; some specimens are of greenish white, with spots of a rusty brown at the largest end.'

"Count Mühle says it comes into Greece at the end of April. On a clear bright morning in spring, the hedges near the coast are often covered with them, though previously none were to be seen. It builds and breeds in the over-grown hills, and goes away early in August. During the breeding-time, the male sits on the tops of the bushes, and continually utters its agreeable, simple, Yellowhammer-like song. It is not at all shy, and is frequently killed by those in quest of it with a stick alone. Singular to say, the female is seldom seen; I have met with a very small number of that sex."

Lieut. R. M. Sperling mentions, in his 'Notes on the Oruithology of the Mediterranean' that he "observed lots of these birds in the high reeds at Butrinto; but they were very artful in dodging out of 
sight;" and Mr. W. H. Simpson, in his 'Ornithological Notes from Mesolonghi and Southern Attolia,' that "the gardens and vineyards were full of this most beautiful bird."

Lord Lilford informs us in 'The Ibis' for 1860, p. 139, that the Black-headed Bunting " arrives in Corfu and Epirus in great numbers in April, remains to breed, and disappears in September, has an agreeable song, and is known in Corfu by the name of 'Ortolano.'"

The Rev. H. B. Tristram, in his 'Notes on the Ornithology of Palestine,' states that it is there a very common aud conspicuous bird in spring and summer, and says :- "On reference to my note-book, I find I did not observe it before the first week in May ; and its plumage is too brilliant for it easily to escape notice. Its note is varied and powerful, more like a Linnet's than a Bunting's; and it resorts to scrub, forests, and cultivated ground, affecting particularly olive-yards and, in the north, apricot-orchards, where it sits pouring forth its song from the topmost twig of some tall tree. The nest is placed either on the ground, in a tuft, or in a low bush, sometimes in the clump at the root of a shrub; it is more compact than that of most Buntings, lined with fibres of roots and hair; and the eggs, often six in number, are of a pale blue, powdered all over their surface, sometimes thickly, at others sparsely, with brown spots."

Mr. Jerdon tells us that "In India the Black-headed Bunting is only found in the North-western Provinces, where it is most abundant in the Deccan, and thence extends into the Upper Provinces of Hindustan. It usually makes its appearance in the Deccan about the end of November, in immense flocks, which are very destructive to the crops of jowaree and other grains. It leaves early in March, and certainly does not breed in any part of India."

Very considerable difference occurs in the appearance of the sexes-the female being destitute of the rich black colouring of the head, and of the chestnut hue of the back.

The male in full breeding-plumage has the head, cheeks, and ear-coverts rich deep black, all the upper surface and a patch on each side of the chest deep rust-red, the whole of the under surface and the sides of the neck bright yellow; wings reddish brown, each feather conspicuously margined with grey, except the primaries, on which it only occurs as a fine line on the extreme edge of the feathers; tail similar, but paler, and the edging not so decided; bill bluish grey; feet yellowish brown.

The general plumage of the female above is brown, each feather margined with pale brown; the under surface washed with yellow, which is deepest on the under tail-coverts.

The figures are of the natural size; the lower one, or female, was taken from the specimen killed at Brighton. 


\section{$2 \mathrm{BHL}$ Biodiversity Heritage Library}

Gould, John. 1873. "Black-headed Bunting, Euspiza melanocephala [PI. 28]." The birds of Great Britain 3, -. https://doi.org/10.5962/p.323919.

View This Item Online: https://www.biodiversitylibrary.org/item/221726

DOI: https://doi.org/10.5962/p.323919

Permalink: https://www.biodiversitylibrary.org/partpdf/323919

\section{Holding Institution}

Smithsonian Libraries

\section{Sponsored by}

Biodiversity Heritage Library

\section{Copyright \& Reuse}

Copyright Status: Public domain. The BHL considers that this work is no longer under copyright protection.

This document was created from content at the Biodiversity Heritage Library, the world's largest open access digital library for biodiversity literature and archives. Visit BHL at https://www.biodiversitylibrary.org. 